\title{
Ihminen tarvitsee holhousta
}

Platon, Lait. Teokset, kuudes osa. Suom. Marja Itkonen-Kaila, Holger Thesleff, Tuomas Anhava, A.M. Anttila, Otava, Helsinki 1986, $409 \mathrm{~s}$.

"Lait" ei ole Platonin tunnetuimpia tai keskeisimpiä teoksia. Sen filosofinen anti, verrattuna tekijän muihin teoksiin, on verraten vähäinen. Teoksen saaminen suomenkielisenä on kuitenkin merkittävää, koska teos on teemoiltaan rinnakkainen Platonin pääteokselle "Valtiolle". "Lait" on astetta käytännönläheisempi kuin "'Valtio". Se antaa meille historiallista tietoa Platonin ajan yhteiskunnasta, käsityksistä ihmisestä yhteiskunnallisena olentona, kasvatuksesta sekä hyvästä ja huonosta valtiosta.

Platonin keskeisen ajatuksen mukaan ihmiset voidaan jakaa kahteen ryhmään: viisaisiin ja vähemmän viisaisiin.
Vähemmän viisaat ovat ihmisten enemmistönä, mutta viisaat puolestaan ovat etevämpiä valtion hallinnon järjestämisessä. Demokratia jakaessaan päätösvallan tasan viisaiden ja tyhmien kesken ei ole kenenkään edun mukaista. On kaikkien edun mukaista antaa viisaiden laatia lait, joiden mukaan yhteiskuntaan luodaan oikea järjestys. Hyvässä yhteiskunnassa jokaisella on oma paikkansa. Platonin "parhaiden diktatuuri" ei siis ole totalitaarinen pakkovallan mielessä, sillä hyvän valtion muodostamiseen käytetään ennen kaikkea suostuttelua ja kasvatusta, ei niinkään pakkoa ja väkivaltaa. Kasvatuksen avulla ihmiset alistuvat holhoukseen. Nykytermein voitaisiin kai puhua eräänlaisesta konsensusyhteiskunnasta tai "sisäistetyn herruuden" järjestelmästä.

Platonin käsitykset kasvatuksesta ovat kiinnostavia. 
Hänelle on läheinen ajatus saman kasvatustapahtuman erilaisesta vaikutuksesta kasvatettaviin. Vaikutus tai merkitys on erilainen riippuen siitä, minkälainen asenne kasvatuksessa on. Esimerkkinä Platon käyttää juominkeja: "juomingeilla on suuri kasvatuksellinen merkitys, jos ne tapahtuvat oikeassa järjestyksessä" (26) Ajatustaan Platon perustelee laajasti sillä, että ihmisessä vaikuttavat "neuvonantajat" - nautinto ja tuska - yhdistyneenä tulevaisuuteen kohdistuviin odotuksiin pääsevät kohtuullisessa humalassa vaikuttamaan vaarattomassa ympäristössä. Ihmisen paheet ja hyveet tulevat koetukselle leikkimielisesti sen sijaan, että olisi kyseessä tosi tilanne. Näin ihminen tuntee itsensä paremmin ja ystävät oppivat tuntemaan hänen piirteensä. Juominkeja ei siten voi tuomita hyväksi tai huonoksi kasvatustapahtumaksi itsessään, vaan on arvioitava niiden merkitystä oikean asenteen ja järjestyksen näkökulmasta. Tähän Platonin esimerkkiin liittyy laajemminkin ajattelemisen arvoi- nen perusero moniin nykykasvatuksen ongelmiin. Platon ei korosta kasvatuksessa hyvien tapojen tai käyttäymismallien opiskelua. Oikea käytös seuraa oikeaa ajattelua ja oikeaa hyveen mukaista toimintaa. Mallit, muodolliset tavat ovat ulkokohtaisia ja haitallisia sekä ihmisen onnen että ajattelun kehittymisen kannalta. Hyviä tapoja ei voi opettaa, ne tulevat hyveen mukana.

Kasvatuksen avulla ihmiset johdatetaan hyväksymään oikea, lakien mukainen järjestys. Lakien merkitys on keskeinen ja siksi niiden laadinta on parhaimpien ja viisaimpien tehtävä. Platonin lait ovat paikoin kovin outoja nykylukijasta. Mutta tärkeämpää kuin niiden outouden huomaaminen on niiden käsittelemien ongelmien tuttuus. On hämmästyttävää huomata kuinka nuori ihmiskunta ja länsimainen kulttuuri on. Vaikka jotkut kohdat oudoksuttavat, valtaosaltaan ei nykylukijalle tuota ongelmia ymmärtää Platonin tekstiä.

Vaikka edellä olen ongelmattomasti olettanut teoksen kirjoittajaksi Platonin, niin näin ei täsmällisesti ottaen ole. Teoksen ovat toimittaneet Platonin oppilaat ja he ovat lisäneet tekstiin mahdollisesti omia näkemyksiään. Tästä johtuen teos vaikuttaa heterogeeniseltä. Teoksen runko on syntynyt ilmeisesti vuoden 350 paikkeilla. Toisaalta tulkinnanvaraisuutta aiheuttaa myös teoksen muoto. Platonille ominaisella tavalla se on dialoginen. Keskustelijoita on kolme: nimeltä mainitsematon ateenalainen (joka edustaa Platonin kantoja) johtaa puhetta, muina keskustelijoina ovat kreetalainen Kleinias ja spartalainen Megillos.

Teos on huolellisesti suomennettu. Se on lisäksi varustettu lyhyellä esittelyllä ja tiiviillä selityksellä. $\mathrm{Ne}$ ovat Holger Thesleffin käsialaa ja auttavat hahmottamaan teoksen kokonaisuutta ja sen yksityiskohtia. Toimituskunnan suururakasta, Platonin teosten kokonaisuudesta puuttuu enää viimeinen, seitsemäs osa.

Pekka Kalli 